\title{
柔軟節の回転特性に基づく周期正方セル構造の短波長座屈モード*
}

\author{
田中展*1, 渋 谷陽二*1,*2
}

\section{Short Wave-Length Buckling Modes of Periodic Square Cell Structures Based on the Rotational Characteristics of Flexible Joints}

\author{
Hiro TANAKA*3 and Yoji SHIBUTANI \\ ${ }^{* 3}$ Department of Mechanical Engineering, Osaka University, \\ 2-1 Yamadaoka, Suita-shi, Osaka, 565-0871 Japan
}

\begin{abstract}
The mechanical properties of spatial structures constructed of joints and beam members are strongly influenced by both their geometrical configurations and joint rigidities. From the standpoint of joint flexibility, we have formulated the elastic deformation model of a two-dimensional flexibly jointed structure with multi-rotational nodes. The aim of this paper is to make clear the relationship between overall buckling characteristic and local rotations of the flexibly jointed structure. To this end, the structural instability of periodic square cells under equi-biaxial compression is evaluated by applying our proposed model, and it is clarified that the short wave-length buckling modes are determined by the combinations of multi-rotational modes of flexible joints.
\end{abstract}

Key Words: Flexible Joint, Square Cell, Short Wave-Length Buckling, Equi-Biaxial Compression

\section{1. 緒言}

微視的単位空間を有する空間構造体は日常に多く 観察される．例えば，建築骨組や大型橋梁は工業的に 特化したマクロな空間構造体であり ${ }^{(1)}$ ，八ニカム材や フォーム材などのセル状材料は一般に高比剛性に優れ た構造材料としてミクロな空間構造体に位置付けられ る ${ }^{(2)}$. 空間構造体ははり部材とそれらを連結する節で 構成され，超軽量性，高機能性扔よび空間制約などの 各種要求に応じた構造設計が可能となるため, その力 学特性を理解することは工学上きわめて重要である.

著者らは,より広い視点から空間構造体がもたらす 多彩な変形様式を理解することを目的として，節の多 回転相互作用に着目した 2 次元柔軟節構造体の弾性変 形モデルを構築し，節の柔軟性に依存した空間構造体 特有の変形機構を見出した ${ }^{(3) \sim(5)}$. 空間構造体の変形様 式の多くは微視構造の回転が伴い，力場は幾何形状に 準ずるモ一メントの相互作用が支配的となる. 座屈分 岐はその代表例であり，微視構造の変形が圧縮から回 転に移行することで構造は対称性を失う. 特に, 六方 セルは工業的用途の豊富さと高対称性に対する物理的

* 原稿受付 2009 年 6 月 1 日.

*1 正員, 大阪大学大学院工学研究科機械工学専攻 (画 565-0871 吹田市山田丘 2-1)

*2 正員, フェロー, 大阪大学大学院工学研究科附属原子分子イ オン制御理工学センター。

E-mail : htanaka@mech.eng.osaka-u.ac.jp
関心から精力的に研究がなされているハニカム材のひ とつであり，面内圧縮下における六方セルの多様な座 屈モードと座屈後挙動が, 実験(6)(7)ならびに有限要素

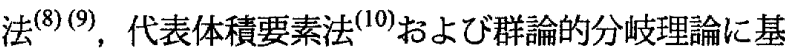

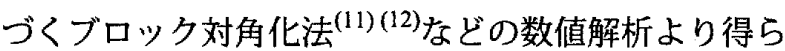
れることが報告されている，一方，正方ハニカムも高 表面積と高比剛性の利点から触媒コンバーターや熱交 換器に応用されており ${ }^{(13)(14)}$, 面内圧縮下における弾 性／弾塑性正方セルの短波長拉よび長波長座屈モード が古典はり理論 ${ }^{(15)}$ や均質化理論によるマルチスケール 解析 ${ }^{(16)(17)}$ 上り求められている。 セル構造体の微視的 分岐と巨視的不安定の関係は周期材料の座屈分岐に対 する関心事のひとつであり ${ }^{(18) \sim(22)}$, 正方ハニカムの場 合, その巨視的不安定点は微視的な正方セルの長波長 座屈に相当することが報告されている ${ }^{(16)}$.

本研究では，節の回転特性に関する基礎知識を充実 させ, 柔軟節構造体の基本的な座屈メカニズムを理解 することを目的とする．そのため，解析対象は等二軸 圧縮下に扔ける柔軟節を有する周期正方セルの短波長 座屈モードに限定する．そこで本論文では，はじめに 柔軟節モデルを定式化し，多回転相互作用を表すへシ アン行列から柔軟節の基本回転モードを導出する. そ して，正方セルの等二軸圧縮座屈解析より求めた座屈 モードの幾何学的対称性と節の回転対称性の相関を 2 面体群 ${ }^{(23)(24)}$ を用いて整理し，得られた結果より柔軟 
節の回転特性が及ぼす正方セルの構造不安定性につい て議論する。

\section{2. 定式 化}

本章では, 文献 ${ }^{(3) \sim(5)}$ に基づいた柔軟節モデルの定式 化を行い, 柔軟節の回転特性および柔軟節構造体の弾 性保存系について記述する。

2.1 柔軟節の多回転エネルギー 有限な 2 次元 領域 $\left[\Omega:=x \times y \subset \mathcal{R}^{2}\right]$ 上で $n$ 組のはりセグメントと連 結する結合節を $n$ 位柔軟節 (joint $(n)$ ) と呼ぶ。このと き， $n$ 位柔軟節は $2+n$ 組の独立な並進／回転自由度 を有し, その一般化変位べクトルおよび一般化荷重べ クトルを以下のように定義する.

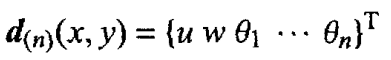

$$
\begin{aligned}
& \boldsymbol{f}_{(n)}(x, y)=\left[\begin{array}{lllll}
P & F & M_{1} & \cdots & M_{n}
\end{array}\right\}^{\mathrm{T}}
\end{aligned}
$$

ここで, $u, w$ は各軸方向の並進変位を表し, $\theta_{i}(i=$ $1, \ldots, n)$ は $i$ 番目の回転変位を表す．ただし，柔軟節 上の結合番号 $i$ は反時計回りでカウントする．また, $P, F$ は各軸方向の集中荷重を表し， $M_{i}$ は $i$ 番目の回 転モーメントを表す， $x$ 軸を基準軸とし，基準軸から の $i$ 番目の初期方位角を ${ }^{0} \theta_{i}$ とすると, $n$ 位柔軟節の相 対結合角 $\theta_{i j}$ は以下のようになる.

$$
\theta_{i j}=\left({ }^{0} \theta_{j}+\theta_{j}\right)-\left({ }^{0} \theta_{i}+\theta_{i}\right), \quad(i, j) \in \mathrm{B}_{n}
$$

ここで, 集合 $\mathrm{B}_{n}$ は以下の結合番号の組み合わせを表す.

$$
\mathrm{B}_{n}=\left\{0<a<b \leq n \mid(a, b) \in \mathcal{N}^{2}\right\}
$$

このとき, $n$ 位柔軟節の多回転エネルギー $U_{(n)}$ を相対 結合角を用いて以下で記述する.

$$
U_{(n)}\left(\left\{\theta_{i j} \mid(i, j) \in \mathrm{B}_{n}\right\}\right)=\sum_{j>i}^{n} \Phi_{i j}\left(\theta_{i j}\right)
$$

ここで, $\Phi_{i j}$ は $\theta_{i j}$ に関する $\mathrm{C}^{2}$-級半正值関数とする. $\Phi_{i j}$ が全て調和関数であり, 初期平衡状態において $U_{(n)}=0$ を満たすとき，式 (5) は次式のように簡易化される.

$$
U_{(n)}=\sum_{j>i}^{n} \frac{1}{2} k_{i j}\left(\theta_{j}-\theta_{i}\right)^{2}
$$

ここで, $k_{i j}$ は各結合間の回転岡性を表す.いま, 初期 状態において相対結合角が等しい回転剛性は等価であ ると仮定する. 本研究では，この仮定を回転剛性の対 称性と呼ぶ. 回転剛性の対称性を課した場合, 最隣接 の相対結合角が全て等しい $n$ 位柔軟節の回転剛性は以 下のように記述できる.

$$
k_{i j}=k_{m} \text { and } k_{m}=k_{n-m}, \quad m=\left\{j-i \mid(i, j) \in \mathrm{B}_{n}\right\}
$$

すなわち， $k_{m}$ は第 $m$ 隣接間の回転剛性を表す.
2.2 柔軟節の基本回転モード＼cjkstart式(5)で与えた多 回転エネルギー $U_{(n)}$ の回転変位に関するへシアン行 列 $\boldsymbol{H}_{(n)} \in \mathcal{R}^{n \times n}$ は次のように求められる.

$$
H_{(n), i j}=\frac{\partial^{2} U_{(n)}}{\partial \theta_{i} \partial \theta_{j}}= \begin{cases}\sum_{k \neq i}^{n} \frac{\partial^{2} \Phi_{i k}}{\partial \theta_{i k}^{2}}, & i=j \\ -\frac{\partial^{2} \Phi_{i j}}{\partial \theta_{i j}^{2}}, & i \neq j\end{cases}
$$

ここで, $\Phi_{i j}$ の定義より各回転変位 $\theta_{i}$ において混合微 分の連続性が保証されるため, 式 (8)のヘシアン行列 は対称行列となる.すすおち, $\boldsymbol{H}_{(n)}=\boldsymbol{H}_{(n)}^{\mathrm{T}}$. したがっ て, 式 (6)-(8) から, 回転剛性の対称性を課した線形 ヘシアン行列 $\overline{\boldsymbol{H}}_{(n)}$ は次式のようになる.

$$
\overline{\boldsymbol{H}}_{(n)}=\sum_{m=1}^{n-1} k_{m}\left(\boldsymbol{I}_{n}-\boldsymbol{I}_{n}^{m}\right)=k_{0} \boldsymbol{I}_{n}-\sum_{m=1}^{n-1} k_{m} \boldsymbol{I}_{n}^{m}
$$

ここで, $k_{0}=\sum_{m=1}^{n-1} k_{m}$ とする. また, $I_{n}^{m} \in \mathcal{R}^{n \times n}$ は以下 の成分表示を満足する行列として定義する.

$$
I_{n, i j}^{m}= \begin{cases}1, & \text { if } j=(i+m) \bmod n \\ 0, & \text { otherwise }\end{cases}
$$

ただし， $\boldsymbol{I}_{n}$ は $n$ 次単位行列を表し， $\boldsymbol{I}_{n}^{0}=\boldsymbol{I}_{n}$ となる. 式 (10)より行列 $\boldsymbol{I}_{n}^{m}$ は以下の二つの演算を満足する.

$$
\boldsymbol{I}_{n}^{a} \boldsymbol{I}_{n}^{b}=\boldsymbol{I}_{n}^{((a+b) \bmod n)}, \boldsymbol{I}_{n}^{c \mathrm{~T}}=\boldsymbol{I}_{n}^{-c}
$$

したがって, 行列 $\boldsymbol{I}_{n}^{m}$ は位数 $n$ の有限巡回群 $\mathrm{C}_{n}$ の各元 に対応した以下の表現行列 $\boldsymbol{T}(\mathrm{g})$ に相当する.

$$
I_{n}^{m}=\boldsymbol{T}(g), g \in \mathrm{C}_{n}=\left\{e, r^{1}, \ldots, r^{m}, \ldots, r^{n-1}\right\}
$$

ここで, $r^{i}$ は $i$ 回の回転変換を表し,$e=r^{0}$ は単位変 換を表す.

式 (9)より行列 $\bar{H}_{(n)}$ は $\boldsymbol{I}_{n}^{m}$ の線形和で記述され，こ の行列形式より $\overline{\boldsymbol{H}}_{(n)}$ は巡回行列に属する ${ }^{(25)(26)}$. この とき，以下で与えた $\overline{\boldsymbol{H}}_{(n)}$ の標準固有值問題を考える.

$$
\overline{\boldsymbol{H}}_{(n)} \xi_{q}=\lambda_{q} \xi_{q}, \quad q=0,1, \ldots
$$

ここで, $\lambda_{q} \in R$ および $\xi_{q} \in \mathcal{R}^{n}$ は $q$ 次の固有值および固 有べクトルを表す. いま, $\xi_{q}^{(i)}$ を以下で定義したとき,

$$
T\left(r^{i}\right) \xi_{q}=\xi_{q}^{(i)}, i=0, \ldots, n-1,
$$

表現行列 $\boldsymbol{T}$ の直交性より次式の関係が成り立つため, $\xi_{q}$ の回転変換に対して式 (13) は不変である.

$$
\begin{aligned}
& \boldsymbol{T}\left(r^{i}\right) \overline{\boldsymbol{H}}_{(n)} \boldsymbol{T}\left(r^{i}\right)^{\mathrm{T}} \boldsymbol{T}\left(r^{i}\right) \boldsymbol{\xi}_{q}=\lambda_{q} \boldsymbol{T}\left(r^{i}\right) \boldsymbol{\xi}_{q} \\
\Leftrightarrow & \boldsymbol{I}_{n}^{i}\left(k_{0} \boldsymbol{I}_{n}-\sum_{m=1}^{n-1} k_{m} \boldsymbol{I}_{n}^{m}\right) \boldsymbol{I}_{n}^{-i} \xi_{q}^{(i)}=\lambda_{q} \xi_{q}^{(i)} \\
\Leftrightarrow & \overline{\boldsymbol{H}}_{(n)} \xi_{q}^{(i)}=\lambda_{q} \xi_{q}^{(i)}
\end{aligned}
$$




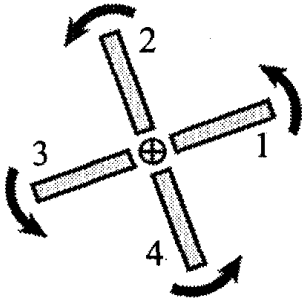

(a)

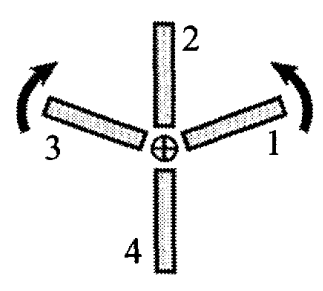

(b)

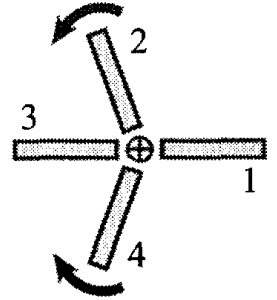

(c)

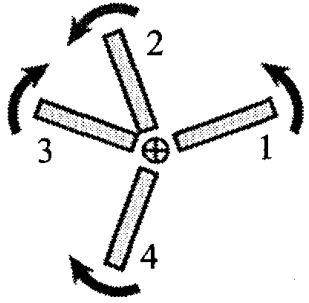

(d)

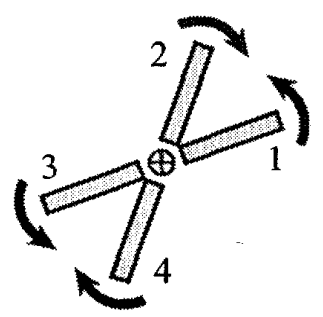

(e)

Fig. 1 Schematic drawings of all possible eigenvectors of unit regular joint (4): (a) a co-rotation mode ( $\xi_{0}$ for $\left.\lambda_{0}=0\right)$, (b)-(d) asymmetrical rotation modes $\left(\xi_{1}^{(0)}, \xi_{1}^{(1)}\right.$, and $\xi_{1}^{(0)}+\xi_{1}^{(1)}$ for $\left.\lambda_{1}=2 k_{1}+2 k_{2}\right)$, (e) a contra-rotation mode ( $\xi_{2}$ for $\lambda_{2}=4 k_{1}$ ). The symbols $\oplus$ show the initial states of regular joints (4).

Table 1 Eigenvalue and eigenvector of $\overline{\boldsymbol{H}}_{(n)}$ for each joint $(n)$ as $n=3 \sim 6$.

\begin{tabular}{|c|c|c|c|c|c|c|c|}
\hline & & $q=0$ & $q=1$ & multiple root & $q=2$ & multiple root & $q=3$ \\
\hline \multirow[b]{2}{*}{$\overline{\boldsymbol{H}}_{(3)}$} & $\lambda_{q}$ & 0 & $3 k_{1}$ & & & & \\
\hline & $\xi_{q} \in \mathcal{R}^{3}$ & $\begin{array}{l}+1 \\
+1 \\
+1\end{array}$ & $\begin{array}{c}+1 \\
-1 / 2 \\
-1 / 2 \\
\end{array}$ & $\left\{\xi_{1}^{(0)}, \xi_{1}^{(1)}, \xi_{1}^{(2)}\right\}$ & & & \\
\hline \multirow[b]{2}{*}{$\bar{H}_{(4)}$} & $\lambda_{q}$ & 0 & $2 k_{1}+2 k_{2}$ & & $4 k_{1}$ & & \\
\hline & $\xi_{q} \in \mathcal{R}^{4}$ & $\begin{array}{l}+1 \\
+1 \\
+1 \\
+1 \\
\end{array}$ & $\begin{array}{r}+1 \\
0 \\
-1 \\
0 \\
\end{array}$ & $\left\{\xi_{1}^{(0)}, \xi_{1}^{(1)}\right\}$ & $\begin{array}{l}+1 \\
-1 \\
+1 \\
-1\end{array}$ & & \\
\hline \multirow[b]{2}{*}{$\overline{\boldsymbol{H}}_{(5)}$} & $\lambda_{q}$ & 0 & $\left(2-\tau_{2}\right) k_{1}+\left(2+\tau_{1}\right) k_{2}$ & & $\left(2+\tau_{1}\right) k_{1}+\left(2-\tau_{2}\right) k_{2}$ & & \multirow[b]{2}{*}{$\begin{array}{l}\tau_{1}=\frac{+1+\sqrt{5}}{2} \\
\tau_{2}=\frac{-1+\sqrt{5}}{2}\end{array}$} \\
\hline & $\xi_{q} \in \mathcal{R}^{5}$ & $\begin{array}{l}+1 \\
+1 \\
+1 \\
+1 \\
+1 \\
\end{array}$ & $\begin{array}{c}+1 \\
+\tau_{2} / 2 \\
-\tau_{1} / 2 \\
-\tau_{1} / 2 \\
+\tau_{2} / 2 \\
\end{array}$ & $\left\{\xi_{1}^{(i)} \mid i=0 \sim 4\right\}$ & $\begin{array}{c}+1 \\
-\tau_{1} / 2 \\
+\tau_{2} / 2 \\
+\tau_{2} / 2 \\
-\tau_{1} / 2\end{array}$ & $\left\{\xi_{2}^{(i)} \mid i=0 \sim 4\right\}$ & \\
\hline \multirow[b]{2}{*}{$\overline{\boldsymbol{H}}_{(6)}$} & $\lambda_{q}$ & 0 & $k_{1}+3 k_{2}+2 k_{3}$ & & $3 k_{1}+3 k_{2}$ & & $4 k_{1}+2 k_{3}$ \\
\hline & $\xi_{q} \in \mathcal{R}^{6}$ & $\begin{array}{l}+1 \\
+1 \\
+1 \\
+1 \\
+1 \\
+1\end{array}$ & $\begin{array}{c}+1 \\
+1 / 2 \\
-1 / 2 \\
-1 \\
-1 / 2 \\
+1 / 2\end{array}$ & $\left\{\xi_{1}^{(0)}, \xi_{1}^{(1)}, \xi_{1}^{(2)}\right\}$ & $\begin{array}{c}+1 \\
-1 / 2 \\
-1 / 2 \\
+1 \\
-1 / 2 \\
-1 / 2\end{array}$ & $\left\{\xi_{2}^{(0)}, \xi_{2}^{(1)}, \xi_{2}^{(2)}\right\}$ & $\begin{array}{l}+1 \\
-1 \\
+1 \\
-1 \\
+1 \\
-1\end{array}$ \\
\hline
\end{tabular}

式(13) の標準固有值問題は, 巡回行列の定理より次 式のように実部の解析解として求まる ${ }^{(26)}$.

$$
\begin{aligned}
& \lambda_{q}=-\sum_{m=0}^{n-1} k_{m} \cos (-2 \pi q m / n) \\
& \boldsymbol{\xi}_{q}=\{1 \cos (-2 \pi q / n) \cdots \cos (-2 \pi q(n-1) / n)\}^{\mathrm{T}}
\end{aligned}
$$

例えば, $n=4$ のとき, 固有值とそれに対応する固有 ベクトルはそれぞれ以下のようになる.

$$
\begin{aligned}
& \lambda_{0}=0 \quad: \quad \xi_{0}=(+1+1+1+1\}^{\mathrm{T}} \\
& \lambda_{1}=2 k_{1}+2 k_{2}: \quad \xi_{1}^{(0)}=\left\{\begin{array}{lll}
+1 & 0-1 & 0
\end{array}\right\}^{\mathrm{T}} \\
& \text { (multiple root) : } \quad \xi_{1}^{(1)}=\left\{\begin{array}{lll}
0+1 & 0-1
\end{array}\right\}^{\mathrm{T}} \\
& \lambda_{2}=4 k_{1} \quad: \quad \xi_{2}=\{+1-1+1-1\}^{\mathrm{T}}
\end{aligned}
$$

ここで, $\xi_{1}^{(2)}, \xi_{1}^{(3)}$ は, 鏡映関係 $\xi_{1}^{(2)}=-\xi_{1}^{(0)}$ と $\xi_{1}^{(3)}=$ - $\xi_{1}^{(1)}$ をそれぞれ満足するため省略する. 式 (18) の各 固有ベクトルは 4 位柔軟節の基本回転モードを表す.
いま，各回転モードに回転変換を作用させると，

$I_{4}^{0} \xi_{0}=I_{4}^{1} \xi_{0}=I_{4}^{2} \xi_{0}=I_{4}^{3} \xi_{0}=\xi_{0}$

$I_{4}^{0} \xi_{1}^{(0)}=\xi_{1}^{(0)}, I_{4}^{1} \xi_{1}^{(0)}=-\xi_{1}^{(1)}, I_{4}^{2} \xi_{1}^{(0)}=-\xi_{1}^{(0)}, I_{4}^{3} \xi_{1}^{(0)}=\xi_{1}^{(1)}$

$I_{4}^{0} \xi_{1}^{(1)}=\xi_{1}^{(1)}, I_{4}^{1} \xi_{1}^{(1)}=\xi_{1}^{(0)}, I_{4}^{2} \xi_{1}^{(1)}=-\xi_{1}^{(1)}, I_{4}^{3} \xi_{1}^{(1)}=-\xi_{1}^{(0)}$

$I_{4}^{0} \xi_{2}=\xi_{2}, I_{4}^{1} \xi_{2}=-\xi_{2}, I_{4}^{2} \xi_{2}=\xi_{2}, I_{4}^{3} \xi_{2}=-\xi_{2}$,

となる. 式 (19)より $\xi_{0}$ は 4 回対称性が保持された共 回転モ一ドである. 一方, $\xi_{1}^{(1)}, \xi_{1}^{(2)}$ およびその線形和 $\boldsymbol{\xi}_{1}^{(1)}+\xi_{1}^{(2)}$ は非対称回転モードであり，また， $\xi_{2}$ は 2 回 対称の反対回転モードである．これら各モードの回転 様式をそれぞれ図 1(a)-(e) に示す. 次に, $n=3$ から $n=6$ までの柔軟節の固有值と基本回転モードの関係を 表 1 に整理する. 表 1 より, 全ての柔軟節は固有值 0 の共回転モード (0次モード) を有する. また, $n=4$ の とき，その全固有べクトルは $\{0, \pm 1\}$ の要素から成り， 互いに直交していることがわかる. 一方, $n=3,5,6$ の場合, 重解の固有值から得られる固有べクトル $\xi_{q}^{(i)}$ 
は回転変換に対して直交関係を満たさない，ただし， 表 1 で与えた $\xi_{q}^{(i)}$ は, 全ての異なる固有值の固有べク トル空間と直交する平面 (直交補空間) 上のベクトルの ひとつであることに注意する. 例えば, $n=30$ 場合, $\left\langle\xi_{0}, \xi_{1}\right\rangle=0$ を満たす任意の $\xi_{1}$ が選択できる.

2.3 柔軟節構造体の弾性保存系 Wま, $N_{\mathrm{j}}$ 組の 柔軟節と $N_{s}$ 組のはりセグメントで構成された安定な 平衡状態を有する 2 次元柔軟節構造体の弾性保存系を 考える. このとき, 系のポテンシャルエネルギーを以 下で与える.

$$
\Pi=\sum_{\alpha=1}^{N_{\mathrm{j}}} U_{(n)}^{\alpha}+\sum_{\beta=1}^{N_{\mathrm{s}}} U_{\mathrm{s}}^{\beta}-W
$$

式 (20) の右辺第 1 項は, 式 (6) で与えた柔軟節の回転 ポテンシャルエネルギーの総和を表す. また, 第 2 項 ははりセグメントのひずみエネルギーの総和を表す。 本モデルにおけるはりセグメントは微小ひずみの仮定 の下, 大変位/大回転を許容する 3 節点はり要素で定 式化されており，文献 ${ }^{(3)}$ に詳細が記述されている. 第 3 項は外力による仕事を表す.いま, 系全体の変位べ クトルを $\boldsymbol{d} \in \mathcal{R}^{f_{\mathrm{j}}+f_{s}}$ で定義し，それに対応する外力べ タトルを $\boldsymbol{f} \in \mathcal{R}^{f_{\mathrm{j}}+f_{\mathrm{s}}}$ で定義する.ここで， $f_{\mathrm{j}}$ は全柔軟 節の総自由度, $f_{\mathrm{s}}$ は全はりセグメントの総自由度を 示す.このとき, 式(20)より系のポテンシャルエネル ギーの $\boldsymbol{d}$ に対する第一変分を以下に得る.

$$
\begin{aligned}
\delta \Pi & =\sum \delta U_{(n)}^{\alpha}+\sum \delta U_{\mathrm{s}}^{\beta}-\delta W \\
& =\left\{\sum \boldsymbol{q}_{(n)}^{\alpha \mathrm{T}}+\sum \boldsymbol{q}^{\beta \mathrm{T}}-\boldsymbol{f}^{\mathrm{T}}\right\} \delta \boldsymbol{d}
\end{aligned}
$$

ここで, $q_{(n)}^{\alpha} \in \mathcal{R}^{n}, q^{\beta} \in \mathcal{R}^{9}$ はそれぞれ柔軟節 $\alpha$ の内 モーメントベクトル括よびはりセグメント $\beta$ の内力べ クトルを表す. 弾性保存系における全ポテンシャルエ ネルギーの停留条件 $\delta \Pi=0$ より, 式 (21) から以下の 非線形方程式が得られる.

$$
f=\sum q_{(n)}^{\alpha}+\sum q^{\beta}=q(d)
$$

さらに, 式(22)の局所線形増分から以下のような接線 剛性行列 ${ }^{t} \boldsymbol{G} \in \mathcal{R}^{\left(f_{\mathrm{j}}+f_{\mathrm{s}}\right) \times\left(f_{\mathrm{j}}+f_{\mathrm{s}}\right)}$ が要素内力ベクトルのヤ コビ行列で導出される.

$$
\begin{aligned}
\Delta \boldsymbol{f} & =\left[\sum \frac{\partial \boldsymbol{q}_{(n)}^{\alpha}}{\partial d_{(n)}^{\alpha}}+\sum \frac{\partial \boldsymbol{q}^{\beta}}{\partial d^{\beta}}\right] \Delta d \\
& =\left[\sum \overline{\boldsymbol{H}}_{(n)}^{\alpha}+\sum{ }^{t} \boldsymbol{K}^{\beta}\right] \Delta d \\
& ={ }^{t} \boldsymbol{G} \Delta d
\end{aligned}
$$

ここで, 行列 $\boldsymbol{K}^{\boldsymbol{\beta}}$ は 3 節点要素のはりセグメント $\beta$ の 接線剛性行列である ${ }^{(3)(4)}$.

\section{3. 周期正方セルの等二軸座屈問題}

3.1 解析条件 第 2 章で述べた柔軟節が有する 基本回転モードを踏まえて，図2(a)に示すような 4 位 柔軟節で連結された正方セルの等二軸圧縮問題を考え る. 荷重負荷を比例荷重係数 $\Lambda$ と参照荷重べクトル $f_{\text {ref }}$ の積で表し, 図 2(b)に示すような変位境界条件を 与える. ここで, 各変位変数の上付添字は図 2(b) の節 点番号に対応し，変位拘束が課された各セル壁の節点 は圧縮以外の変位に対して周期条件を満足している. また，セル壁上の回転変位も周期条件を満たすとする. はり部材は 3 節点要素で 10 要素に分割され，その部 材長を $L=20$ とする. そして, はり部材の軸剛性およ び曲げ剛性をそれぞれ $E A=200.0, E I=2.0$ とする. 本解析では，図 3 に示すような 2 種類の 4 位柔軟節を 用いる. 図3(a) は，最隣接はり部材間のみに回転ばね を内㨉した柔軟節モデルであり，Joint A と呼称する. また，図3(b)は，半剛節はりが剛連結した柔軟節モデ ルを表し, Joint B と呼称する.これらのへシアン行列 はそれぞれ以下のように表される.

$\overline{\boldsymbol{H}}_{(4)}^{\mathrm{A}}=\frac{k}{4}\left[\begin{array}{rrrr}2 & -1 & 0 & -1 \\ -1 & 2 & -1 & 0 \\ 0 & -1 & 2 & -1 \\ -1 & 0 & -1 & 2\end{array}\right], \quad \overline{\boldsymbol{H}}_{(4)}^{\mathrm{B}}=\frac{k}{4}\left[\begin{array}{rrrr}3 & -1 & -1 & -1 \\ -1 & 3 & -1 & -1 \\ -1 & -1 & 3 & -1 \\ -1 & -1 & -1 & 3\end{array}\right]$

ここで, 回転剛性を $k=2 \mu E I / L$ で表し, $\mu$ を柔軟係数 とする. $\mu \rightarrow \infty$ のそ, この柔軟節は剛節に近似さ

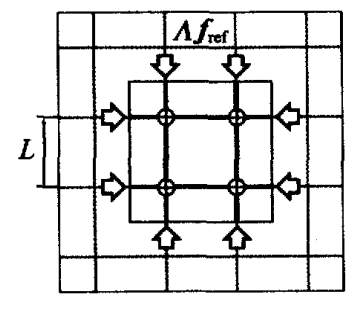

(a)

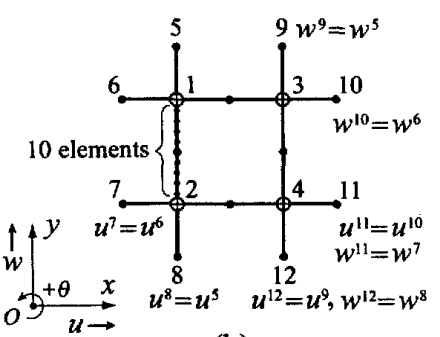

(b)
Fig. 2 Analytical model of a flexible jointed structure with $2 \times 2$ square cells: (a) a loading condition, (b) displacement boundary conditions.

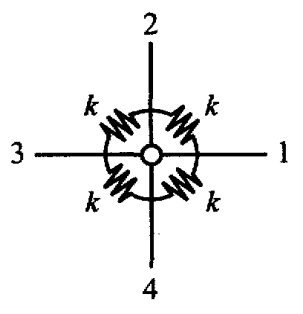

(a) Joint $\mathrm{A}$

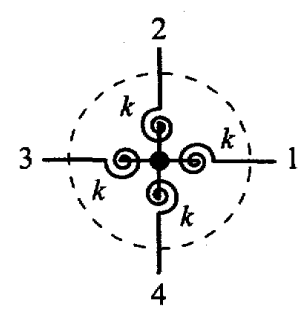

(b) Joint B
Fig. 3 Two types of flexible joints (4). 


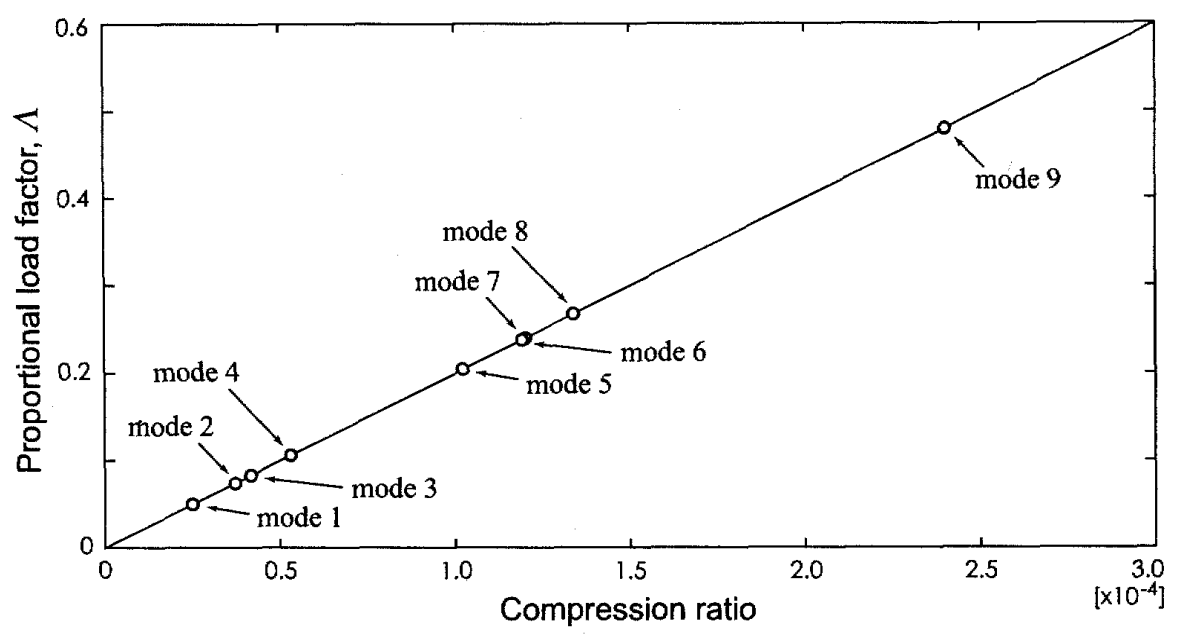

Fig. 4 Bifurcation points from mode 1 to mode 9 as 'Joint A' modeling for $\mu=1$.

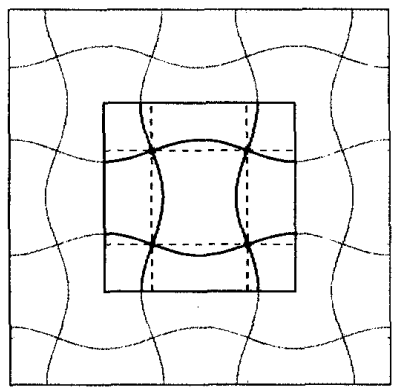

(a) mode 1

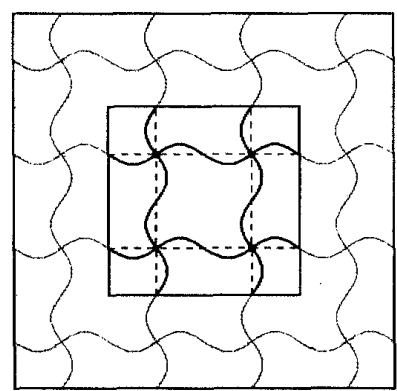

(e) mode 5

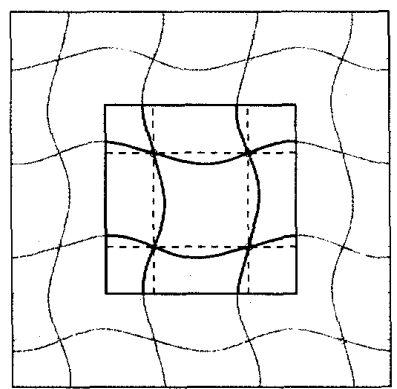

(b) mode 2

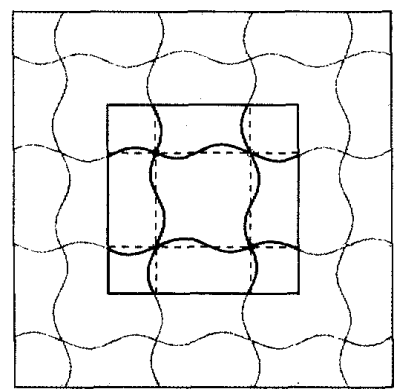

(f) mode 6

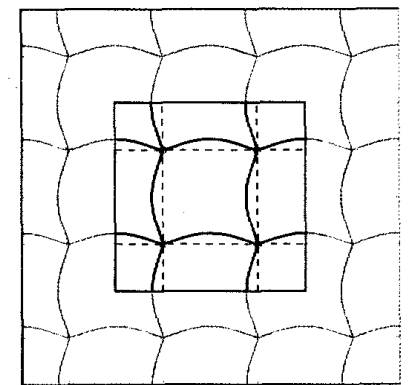

(c) mode 3

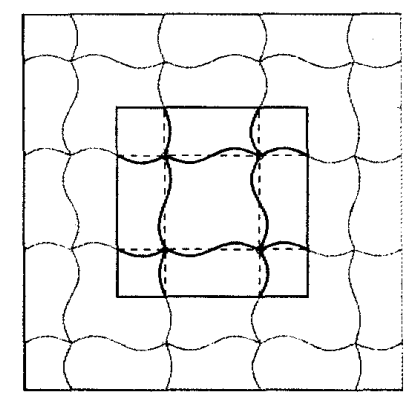

(g) mode 7

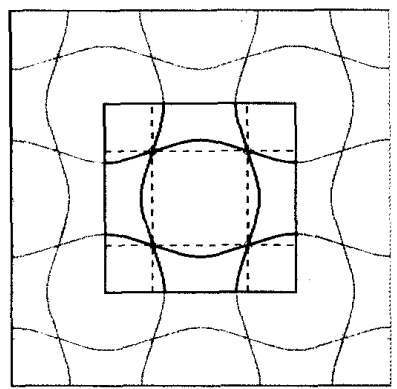

(d) mode 4

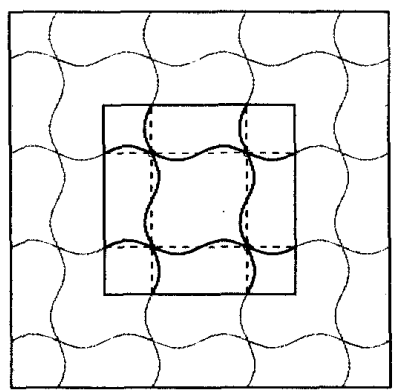

(h) mode 8

Fig. 5 Measured buckling shapes of square cells under biaxial compression: (a)-(h) mode $p,(p=1, \ldots, 8)$. The deformation modes shown here are greatly magnified for clarity.

れ， $\mu \rightarrow 0$ のときは滑節に近似される. 式(24) の導出 に関しては文献 ${ }^{(5)} に$ 詳細が記述されている.

\section{2 数值解析結果 図 2 の解析モデルを対象に}

して, 比例載荷系 $\boldsymbol{q}\left({ }^{t} \boldsymbol{d}\right)={ }^{t} \Lambda f_{\mathrm{ref}}$ にお打る接線剛性行列 ${ }^{t} \boldsymbol{G}$ が非正則 $\operatorname{det}\left({ }^{t} \boldsymbol{G}\right)=0$ であるとき, 座屈点と判定す る.このとき, $p$ 次座屈点に捣てクリティカルな座 屈係数 $\Lambda_{p}^{\mathrm{c}}$ および座屈モード $\phi_{p}^{(i) \mathrm{c}}$ を以下で定義する.

$$
\boldsymbol{G}\left(\Lambda_{p}^{\mathrm{c}}\right) \boldsymbol{\phi}_{p}^{(i) \mathfrak{c}}=\mathbf{0}, \quad p=1,2, \ldots, i=1, \ldots, M
$$

ここで，座屈係数 $\Lambda_{p}^{\mathrm{c}}$ を $\Lambda_{1}^{\mathrm{c}} \leq \Lambda_{2}^{\mathrm{c}} \leq \cdots$ と順に並べる. また，上付添字 $(i)$ は分岐の多重度を表す。なお，本 数值解析においては, $\operatorname{det}\left({ }^{\prime} G\right)$ の正負符号の反転を利用
した二分法より座屈点を判定している(27).

はじめに，柔軟係数 $\mu=1$ のとき，Joint A の柔軟節 モデルに対して得られた各座屈モードの分岐点を図 4 に示す．ここで, 縦軸は比例荷重係数 $\Lambda$ を, 横軸は圧 縮率 $u^{6} / L$ (図 2(b) 参照) を表す. また, $p$ 次座屈点に対 応した各座屈形状をそれぞれ図 5(a)-(h) に示し, mode $p$ と呼ぶ. 図 5(a) に示す mode 1 は最低次の座屈モ一 ドであり，隣接する節が互いに逆方向に共回転するこ とで生成される．この座屈モードは，一般的な剛節骨 組構造の理論解 ${ }^{(15)}$ および数值解析解 ${ }^{(16)}$ として得られ, 柔軟節の回転特性は需与しない。一方, mode 2 およ び mode 3 は共回転以外の回転モードが座屈に作用し, 


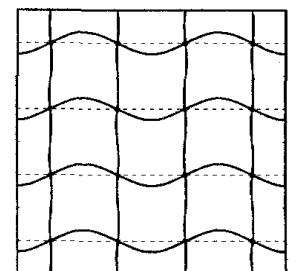

(a) $\phi_{2}^{(1) c}$

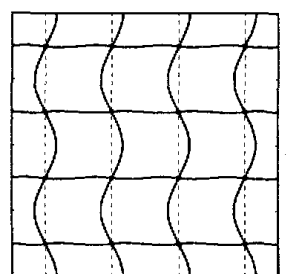

(b) $\phi_{2}^{(2) c}$

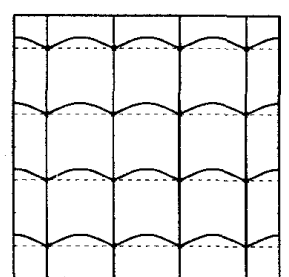

(c) $\phi_{3}^{(1) c}$

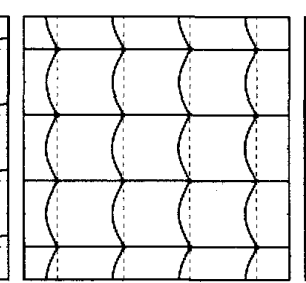

(d) $\phi_{3}^{(2) c}$

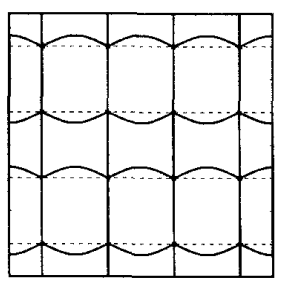

(e) $\phi_{3}^{(3) c}$

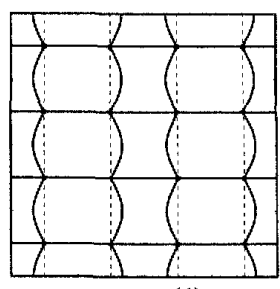

(f) $\phi_{3}^{(4) \mathrm{c}}$

Fig. 6 A pair of orthogonal eigenvector modes for mode 2: (a) $\phi_{2}^{(1) \mathrm{c}}$ and (b) $\phi_{2}^{(2) c}$. Two pairs of orthogonal eigenvector modes for mode 3: (c-f) $\phi_{3}^{(i) c}(i=1, \ldots, 4)$. The figures $5(\mathrm{~b})$ and (c) correspond to the linear sum of their modes: (mode 2) $\phi_{2}^{(1) \mathrm{c}} / \sqrt{2}+\phi_{2}^{(2) \mathrm{c}} / \sqrt{2}$, (mode 3$) \phi_{3}^{(1) \mathrm{c}} / \sqrt{2}+\phi_{3}^{(2) \mathrm{c}} / \sqrt{2}$.

Table 2 Buckling modes ( $p=1 \sim 5$ ) of $2 \times 2$ square cells under equi-biaxial compression.

\begin{tabular}{cclcc}
\hline mode & overall eigen vector & overall symmetry reduction & joint rotation & joint symmetry \\
\hline \hline$p=1$ & $\pm \phi_{1}^{\mathrm{c}}$ & $\mathrm{D}_{4} \rightarrow \mathrm{D}_{2}^{1,4}, \mathrm{D}_{2}^{2,4}$ & $\xi_{0}$ & $\mathrm{C}_{4}$ \\
$p=2$ & $\pm \phi_{2}^{(1) \mathrm{c}} / \sqrt{2} \pm \phi_{2}^{(2) \mathrm{c}} / \sqrt{2}$ & $\mathrm{D}_{4} \rightarrow \mathrm{D}_{1}^{1,4}, \mathrm{D}_{1}^{2,4}, \mathrm{D}_{1}^{3,4}, \mathrm{D}_{1}^{4,4}$ & $\left\{\xi_{0}, \xi_{2}\right\}$ & $\mathrm{C}_{4}, \mathrm{C}_{2}$ \\
$p=3$ & $\pm \phi_{3}^{(1) \mathrm{c}} / \sqrt{2} \pm \phi_{3}^{(4) \mathrm{c}} / \sqrt{2}$ & $\mathrm{D}_{4} \rightarrow \mathrm{D}_{1}^{1,4}, \mathrm{D}_{1}^{2,4}, \mathrm{D}_{1}^{3,4}, \mathrm{D}_{1}^{4,4}$ & $\left\{\xi_{1}^{(1)}, \xi_{1}^{(2)}\right\}$ & $\mathrm{C}_{1}$ \\
& $\phi_{3}^{(3) \mathrm{c}} / \sqrt{2}+\phi_{3}^{(4) \mathrm{c}} / \sqrt{2}$ & $\mathrm{D}_{4} \rightarrow \mathrm{D}_{4}$ & $\left\{\xi_{1}^{(1)}, \xi_{1}^{(2)}\right\}$ & $\mathrm{C}_{1}$ \\
& $\phi_{3}^{(3) \mathrm{c}} / \sqrt{2}-\phi_{3}^{(4) \mathrm{c}} / \sqrt{2}$ & $\mathrm{D}_{4} \rightarrow \mathrm{D}_{2}^{1,4}, \mathrm{D}_{2}^{2,4}$ & $\left\{\xi_{1}^{(1)}, \xi_{1}^{(2)}\right\}$ & $\mathrm{C}_{1}$ \\
$p=4$ & $\pm \phi_{4}^{\mathrm{c}}$ & $\mathrm{D}_{4} \rightarrow \mathrm{D}_{4}$ & $\xi_{2}$ & $\mathrm{C}_{2}$ \\
$p=5$ & $\pm \phi_{5}^{\mathrm{c}}$ & $\mathrm{D}_{4} \rightarrow \mathrm{C}_{4}$ & $\xi_{0}$ & $\mathrm{C}_{4}$ \\
\hline
\end{tabular}

\section{これらの座屈モードは多重分岐となる。}

mode 2 では, 図 6(a), (b) で示す 1 対の直交したクリ ティカルな固有べクトル $\phi_{2}^{(1) \mathrm{c}}$ および $\phi_{2}^{(2) \mathrm{c}}$ を有する 2 重分岐となる. 図 5(b) に示す mode 2 はこの 1 対の固 有べクトルの線形和 $\cos \gamma \phi_{2}^{(1) \mathrm{c}}+\sin \gamma \phi_{2}^{(2) \mathrm{c}}(\gamma=\pi / 4)$ で 表され，係数の正負の組み合わせにより系の対称性が 4 軸対称から 4 パターンの 1 朝対称に低下する. mode 2 の特徴は， 2 組の共回転モード $\xi_{0}$ と 2 組の反対回転 モード $\xi_{1}$ で構成され，座屈係数が mode 1 に次いで小 さくなる点である. mode 3 の座屈モードでは, 2 対の クリティカルな固有ベクトル $\phi_{3}^{(1) \mathrm{c}}, \phi_{3}^{(2) \mathrm{c}}$ と $\phi_{3}^{(3) \mathrm{c}}, \phi_{3}^{(4) \mathrm{c}}$ を有する. その形状を図 6(c)-(f) に示すように各固有

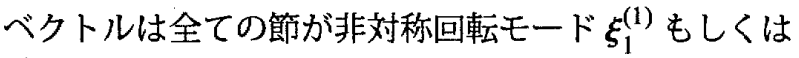
$\xi_{1}^{(2)}$ で表現されている. 例えば, $\xi_{1}^{(1)}$ の場合は図 6(c), (e) より $x$-軸方向の座屈モードを生成し, また, $\xi_{1}^{(2)} の$ 場合は図 6(d), (f) より $y$-軸方向の座屈モードを生成す る. 4 組のクリティカルな固有ベクトルを有するが, 直 交関係をもつ固有べクトル以外が同時に重なり合うこ とはない. mode 4 の座屈モードは, 図 5(d) に示すよ うに全て柔軟節の反対回転モード $\xi_{2}$ で構成された単 純分岐点となる. 系全体の対称性が変化しない mode 4 は一般に全対称モードと呼ばれるが, 柔軟節の局所 的な回転対称性は低下している.

全ての柔軟節が同方向の共回転モードを示す mode 5 は, 各はり部材が 1 波長の座屈形状となり, 高次の
座屈モードに位置付けられる. mode 1 から mode 5 ま での座屈モードに対する系の対称性の変化と柔軟節の 回転モードの関係を表 2 に整理する.ここで, $\mathrm{D}_{n}, \mathrm{D}_{m}^{k, n}$ はそれぞれ 2 面体群扰よびその部分群を表す(23)(24). 表 2 が示すように, 座屈モードの順序は局所的な柔軟 節の回転モードに依存する. そして，選択された回転 モードと周期境界条件に基づいて系の対称性が決定さ れる. 同様に, 各はり部材のたわみが 1 波長になる高 次座屈モードにおいても，座屈モードの順序は柔軟節 の回転モードに依存する (図 5(e)-(h) 参照).

次に, Joint A と Joint B の柔軟節モデルにおいて, 柔軟係数 $\mu$ を変化させたときの各モードの座屈値の 変動を調べる. 図 7(a), (b) に各モデルの座屈值と柔軟 係数の関係を示す.ここで, 縦軸の座屈值は mode 1 の座屈係数で無次元化されている. 図 7(a), (b) より, mode 1 および mode 5 は柔軟係数に依らず両モデルと もに定值を示す。これは, mode 1 および mode 5 の座 屈モードが柔軟節の共回転モード（固有值 0) で構成 されているためである. また, Joint Bでは mode 3 と mode 4 の座屈值が完全に一致するのに対して, Joint A では mode 3 が mode 4 から分離する. この理由は, Joint A のヘシアン行列の場合, 式 (18)より非回転対 称モードの固有值 $k / 2$ が反対回転モードの固有值 $k$ よ り小さくなるためである. 一方, Joint B では両回転 モードの固有值は等しいため区別されない，また，柔 


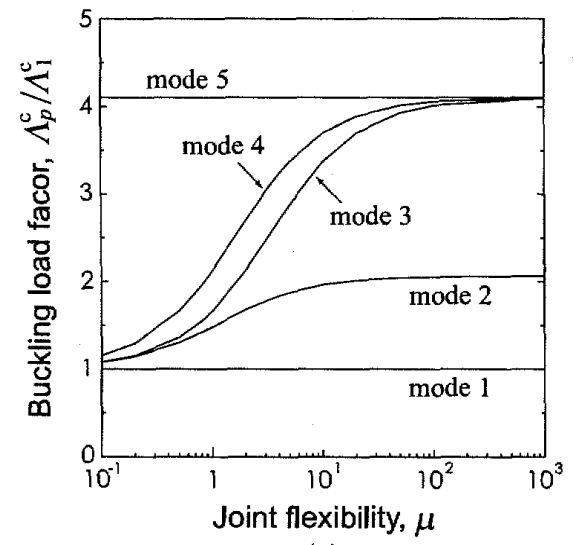

(a)

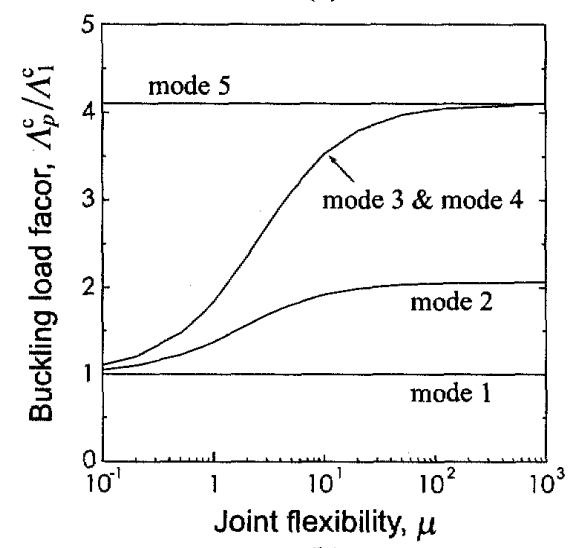

(b)

Fig. 7 Relationship between normalized buckling load factor $\Lambda_{p} / \Lambda_{1}$ and joint flexibility $\mu$ : (a) Joint A, (b) Joint $\mathrm{B}$.

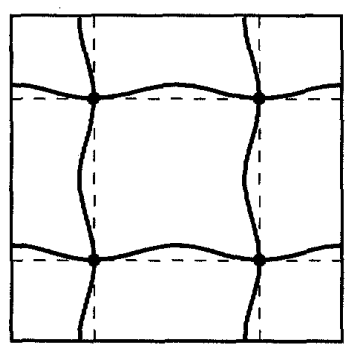

(a)

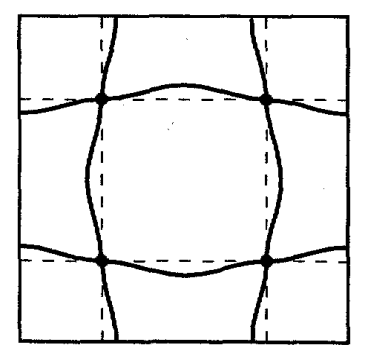

(b)
Fig. 8 Measured buckling shapes of square cells with fully rigid joints: (a) mode 3 , (b) mode 4 .

軟係数の極限に着目すると, $\mu \rightarrow 0$ のとき mode $2 \sim 4$ の座屈值が mode 1 の座屈值まで単調減少する. 一方, $\mu \rightarrow \infty$ のとき mode 3,4 の座屈值は mode 5 に漸近す る. 例えば，剛節時の mode 3 と mode 4 の座屈モード を図 8(a),(b)に示すように，節上で回転が生じないた め等価な変形エネルギーを要することがわかる。

以上のように，共回転モード以外で構成されている 座屈モードは, その座屈值が節の柔軟性に強く依存 するため，柔軟節構造体特有の座屈モードであると考 える.

\section{4. 考察}

柔軟節構造体モデルの目的は, 柔軟節の多回転を含 む一般化変位を用いて回転モーメントが支配的となる 空間構造体の変形挙動を表現することである. 2.では, 材料質点上で共役な多自由度の回転変位とモーメント を定義し, 結合隣接間の相互作用を回転剛性で記述し た. これは, 細長比の大きい部材を 1 次元はり要素で 近似するのと同様に，有限な体積の結合部を多回転相 互作用を介する節点で近似したことを意味する. 本論 文で定義された柔軟係数 $\mu$ は $\mu \propto k L / E I$ の関係を有す ることから, 節の柔軟性は対象構造の材料パラメータ とサイズパラメータによって相対的に決定される.こ のように結合部の定性的な回転相互作用をモデル化し た柔軟節より, 式 (16),(17) のように基本回転モード とその固有值が容易に求められる.

また，3.では，はじめに等二軸圧縮下における正方 セルの短波長座屈モードが柔軟節の基本回転モードで 簡潔に整理できることを明らかにした.これは正方セ ルの座屈形状に対して 4 位柔軟節の局所的回転特性が 密接に寄与していることを示唆する. さらに，図7(a), (b)に招いて柔軟係数と各モードの座屈值の関係を示 した. この結果, 最低次モードの座屈值は柔軟係数に 依存しないことから, 工学的な座屈問題において節の 回転剛性は必ずしも必要ではないことがわかる.一方, 高次モード (mode 2,3,4) の座屈值は柔軟係数に依存 し，その座屈特性は 4 位柔軟節の回転特性と関連付け られた. 本論文では, 式 (24) で定式化した Joint A と Joint B を代表にして, 基本回転モードの固有值 $\left(k_{1}\right.$ と $k_{2}$ の組み合わせ) が座屈値の主因子であることを明ら かにした. この結果より，多様な 4 位柔軟節の結合形 態 ${ }^{(5)}$ に対しても，その回転剛性 $k_{1}$ と $k_{2}$ から各モード の座屈值が予測可能となる. 最低次以上の座屈モード は物理的に顕在化しにくい.このような高次モードを 誘起させるためには，基本回転モードを初期不整量と して与えるなど柔軟節の回転特性を考慮に入れた新し い構造制御の概念が必要となる.

\section{5. 結 言}

2 次元柔軟節構造体の弾性変形モデルを用いて, 等 二軸圧縮下に扔ける柔軟節正方セルの短波長座屈モ一 ドを解析し，系全体の座屈特性と局所的な 4 位柔軟節 の回転特性の関係について議論した. 本研究で得られ た知見を以下に整理する.

(1) 柔軟節のヘシアン行列の固有值と固有ベクトルを 巡回行列の性質から導出し，4 位柔軟節が有する 3 種類の基本回転モードを具体的に示した. 
(2) 等二軸圧縮下における周期正方セル $(2 \times 2$ セル集 合)の短波長座屈モードを計算した，そして，得 られた座届モードが 4 位柔軟節の局所的な回転 モードの組み合わせで決定されることを示した.

（3）正方セルの最低次の座屈モードは，節の共回転 モードで構成されており，その座屈值は柔軟係数 に依存しない，一方，共回転モード以外で構成さ れる座屈モードでは, その座屈值が柔軟係数に依 存し, 剛節や滑節で連結された正方セルの座屈值 から分離することを示した.

\section{謝辞}

なお, 本研究の一部は, 財団法人総合工学振興会の研 究奨励金および科学研究費補助金萌芽研究 (20656020) の助成により行われたものである.ここに記して謝意 を表する。

\section{文献}

(1) Saito, K., The Story of Spatial Structures - A Turning Point for Structural Design (in Japanese), (2003), Shoukokusha Co., Ltd.

(2) Gibson, L.J. and Ashby, M.F., Cellular Solids: Structure and Properties, Second Edition, (1997), Cambridge University Press, Cambridge, UK.

(3) Tanaka, H. and Shibutani, Y., Large Deformability of 2D Framed Structures Connected by Flexible Joints, Journal of Solid Mechanics and Materials Engineering, 2-8 (2008), 1037-1048.

(4) Tanaka, H., Study on the Deformability and Structural Instability of Flexibly Jointed Structures (In Japanese), (2009), Doctoral Thesis (Osaka Univ.).

(5) Tanaka, H. and Shibutani, Y., In-plane Mechanical Behaviors of 2D Repetitive Frameworks with Fourcoordinate Flexible Joints and Elbowed Beam Members, Journal of the Mechanics and Physics of Solids, (in press).

(6) Papka, S.D. and Kyriakides, S., In-plane Compressive Response and Crushing of Honeycomb, Journal of the Mechanics and Physics of Solids, 42 (1994), 1499-1532.

(7) Papka, S.D. and Kyriakides, S., Biaxial Crushing of Honeycombs-Part I: Experiments, International Journal of Solids and Structures, 36 (1999), 4367-4396.

(8) Guo, X.E. and Gibson, L.J., Behavior of Intact and Damaged Honeycombs: A Finite Element Study, International Journal of Mechanical Sciences, 41 (1999), 85-105.

(9) Papka, S.D. and Kyriakides, S., In-plane Biaxial Crushing of Honeycombs-Part II: Analysis, International Journal of Solids and Structures, 36 (1999), 4397-4423.

(10) Hohe, J. and Becker, W., Effective Mechanical Behavior of Hyperelastic Honeycombs and Two-dimensional Model Foams at Finite Strain, International Journal of Mechanical Sciences, 45 (2003), 891-913.

(11) Saiki, I., Ikeda, K. and Murota, K., Appropriate Number of Unit Cells in a Representative Volume Element for
Micro-structural Bifurcation Encountered in a Multi-scale Modeling, Computer Methods in Applied Mechanics and Engineering, 191 (2002), 2561-2585.

(12) Saiki, I., Terada, K., Ikeda, K. and Hori, M., Flower Patterns Appearing on a Honeycomb Structure and their Bifurcation Mechanism, International Journal of Bifurcation and Chaos, 15 (2005), 497-515.

(13) Ichikawa, Y., Umehara, K., Yamada, T., Hijikata, T. and Katsube, F., Advanced Ceramic Substrate: Catalytic Performance Improvement by High Geometric Surface Area and Low Heat Capacity, SAE Paper, (1997), 971029.

(14) Hayes, A.M., Wang, A., Dempsey, B.M. and McDowell, D.L., Mechanics of Linear Cellular Alloys, Mechanics of Materials, 36 (2004), 691-713.

(15) Wah, T., The Buckling of Gridworks, Journal of the Mechanics and Physics of Solids, 13 (1965), 1-16.

(16) Ohno, N., Okumura, D., Niikawa, T., Long-wave Buckling of Elastic Square Honeycombs Subjected to In-plane Biaxial Compression, International Journal of Mechanical Science, 46 (2004), 1697-1713.

(17) Erami, K., Ohno, N. and Okumura, D., Long-wave In-plane Buckling of Elastoplastic Square Honeycombs, International Journal of Plasticiy, 22 (2006), 1569-1585.

(18) Abeyaratne, R. and Triantafyllidis, N., An Investigation of Localization in a Porous Elastic Material Using Homogenization Theory, Transactions of the ASME, Journal of Applied Mechanics, 51 (1984), 481-486.

(19) Triantafyllidis, N. and Schraad, M., Onset of Failure in Aluminum Honeycombs under General In-plane Loading, Journal of the Mechanics and Physics of Solids, 46 (1998), 1089-1124.

(20) Ohno, N., Advances in Microscopic Bifurcation Analysis of Cellular Meterials, Transactions of the Japan Society of Mechanical Engineers, Series A, 68 (2002), 1498-1504.

(21) Ohno, N., Okumura, D. and Noguchi, H., Microscopic Symmetric Bifurcation Condition of Cellular Solids Based on a Homogenization Theory of Finite Deformation, Journal of the Mechanics and Physics of Solids, 50 (2002), 1125-1153.

(22) Okumura, D., Ohno, N. and Noguchi, H., Microscopic Bifurcation and Macroscopic Localization in Periodic Cellular Solids: Elastoplastic Analysis Based on a Homogenization Theory, Transactions of the Japan Society of Mechanical Engineers, Series A, 69 (2003), 1421-1428.

(23) Ikeda, K. and Murota, K., Imperfect Bifurcation in Structures and Materials: Engineering Use of Grouptheoretic Bifurcation Theory, (2002), Springer: New York.

(24) Fujii, F., Ohsaki, J. and Ikeda, K., Mechanics of Bifurcation of Structures and Solids, (2005), Corona Publishing Co., Ltd.

(25) Davis, P.J., Circulant Matrices, (1979), A WileyInterscience Pub., NewYork.

(26) Gray, R.M., Toeplitz and Circulant Matrices: A Review, (2006), Now Publishers Inc.

(27) Hisada, T. and Noguchi, H., Foundations and Applications of Nonlinear Finite Element Method (in Japanese), (1995), p.310, Maruzen Co., Ltd. 